\title{
Superposition of shear zones during orogenic development: an example from the NW Variscan Belt (Viana do Castelo, NW Portugal)
}

\author{
Jorge Pamplona $^{\mathrm{a}, *}$, Gabriel Gutiérrez-Alonso ${ }^{\mathrm{b}}$, António Ribeiro ${ }^{\mathrm{c}}$ \\ ${ }^{a}$ Centro de Investigação Geológica, Ordenamento e Valorização de Recursos, Universidade do Minho, 4710-057 Braga, Portugal \\ ${ }^{\mathrm{b}}$ Departamento de Geología, Universidad de Salamanca, 37008 Salamanca, Spain \\ ${ }^{\mathrm{c}}$ Departamento de Geologia e Laboratório de Tectonofísica e Tectónica Experimental, Universidade de Lisboa, 1749-016 Lisboa, Portugal
}

Received 8 December 2004; received in revised form 14 February 2006; accepted 23 March 2006

\begin{abstract}
The Viana do Castelo region of NW Portugal is the only domain in the West Variscan where the transition from the $\mathrm{D}_{1}$ strike-slip structures to the $\mathrm{D}_{1}$ east vergent flat-lying structures, formed during Devonian-Carboniferous continental collision, has been recognized. Although intrusion of voluminous granite bodies has resulted in extensive recrystallization of host rocks, kinematic analysis of these rocks, using mesoscopic criteria and quartz CPOs (crystallographic preferred orientation) reveals shear senses coherent with the field evidence and suggests that $\mathrm{D}_{1}$ deformation was partitioned into transpressional and compressional components. We also interpret the strain patterns to the effects of non-cylindrical superposed shear zones. The above aspects can be useful to understand the complex tectonic evolution of the most internal zone of the Variscan Belt and of other internal zones of collisional orogenic belts with similar characteristics.
\end{abstract}

(C) 2006 Published by Elsevier Ltd.

Keywords: Evolution of internal zones of Variscan Belt; Partition of deformation; Superposed shear zones; Quartz CPOs

\section{Introduction}

Multi-phase development of the internal zones of orogenic belts is characterized by the superposition of ductile structures, mainly shear zones, with different kinematic components developed under different metamorphic conditions. Within the internal zones, shear zone development is commonly coeval with granitoid generation and emplacement and both processes record the evolution of the different deformation regimes in space and time. The sequential record of shear fabric generation and related structures is commonly obscured by subsequent tectonothermal events that result in partial annealing of these fabrics. As a result of these complexities, it is commonly very difficult to unravel the kinematic significance of earlier structures.

The NW Iberian Variscan arcuate belt is a classic orogenic belt where the multi-phase development of the Variscan structures in its internal zones has been recognized and described (Ribeiro et al., 1990a,b; Martinez-Catalán et al.,

\footnotetext{
* Corresponding author. Tel.: +351253 604307; fax: +351253678206.

E-mail address: jopamp@dct.uminho.pt (J. Pamplona).
}

0191-8141/\$ - see front matter (C) 2006 Published by Elsevier Ltd. doi:10.1016/j.jsg.2006.03.029
1996; Dallmeyer et al., 1997). The orogenic development of the Variscan Belt is the result of the Devonian-Carboniferous collision between Gondwana and Laurentia that caused the major, shortening-related structures with displacements normal to the general strike of the belt. In addition, the arcuate shape of the belt suggests that crustal-scale strike-parallel structures may accommodate some of the across-strike shortening (Matte and Ribeiro, 1975; Iglesias and Choukroune, 1980; Ferreira et al., 1987; Llana-Fúnez and Marcos, 2001; Gutiérrez-Alonso et al., 2004). Based on paleomagnetic evidence in the external zones, such structures have been interpreted to have originated during the latest stages of the collision (Weil et al., 2001). The strike-slip crustal shear zones have been also interpreted to have facilitated the emplacement of many of the granitoid bodies present in NW Iberia (Aranguren and Tubía, 1994).

In this study, we describe and interpret the structures present in the studied area and the sequence of deformational events causing them, in a region where the aforementioned major deformation phases existing in the NW Iberian Variscan Belt show their geometric and kinematic relationships. The mentioned structures are recognized along a NNW-SSEtrending deformation corridor located in the proximity of Viana do Castelo (NW Portugal) (Fig. 1). We present a detailed structural analysis of the region emphasizing the kinematics of the shear zones and the relationships among them and the 

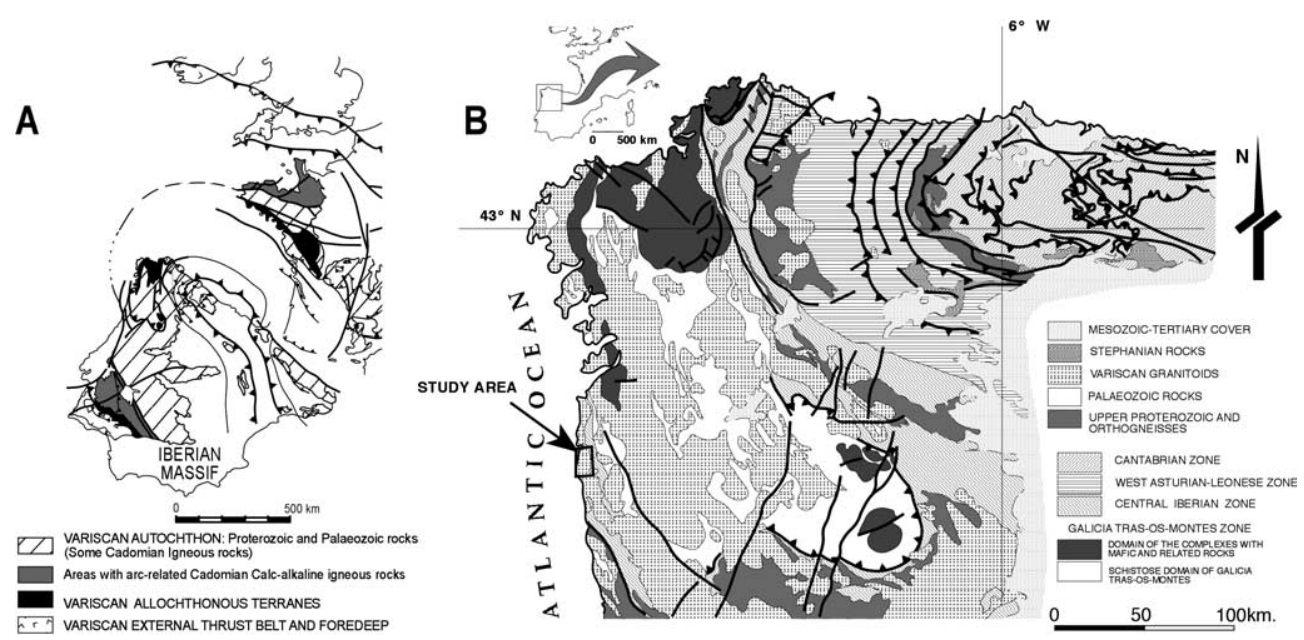

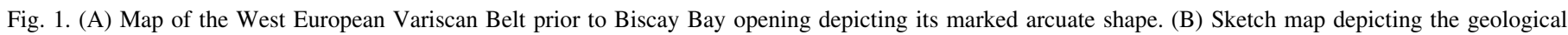

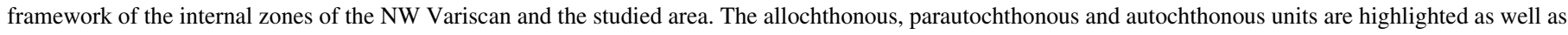
the main thrusts and strike slip faults.

regional structure. The kinematic analysis has been done using both mesoscopic structural criteria and quartz CPOs (crystallographic preferred orientation). In this corridor, the dating of granitic intrusions provides precise time constraints that enable different deformational episodes found in this area to be placed in chronological sequence.

The presence of a large volume of granitic intrusions has recrystallized the host rocks to varying different degrees, limiting the information provided by the quartz CPOs in the studied region. However, we propose a kinematic and structural sequence in the region and correlate these events with those described in the surrounding areas. We also interpret the relationship between the superposed shear zones and the different intrusive modes of the granite bodies. Taken together, these features constrain the tectonic evolution of the internal zone of the Variscan Belt and provide insights into processes occurring in other collisional orogenic belts.

\section{Geological setting}

NW Iberia Variscan geological framework (Fig. 1) consists of a structural stack of thrust slices that can be grouped into three main structural units. The uppermost thrust slice, known as the allochthonous unit, sits above the Variscan suture and the subducted terranes of Gondwanan affinity (Arenas et al., 1986, 1995; Ribeiro et al., 1990a; Martinez-Catalán et al., 1999; Fernández-Suárez et al., 2003). The allochthonous unit is variously interpreted to be composed either of Laurentian affinity rocks or of rocks with an Armorican affinity (Marques et al., 1996). The latter interpretation implies that the suture with Laurentia must exist further west. Below it, and separated by a large thrust, the parautochthonous unit contains Silurian and Devonian sediments from the Gondwanan margin that were located in the most seaward position and that were not subducted during orogenesis (Iglesias et al., 1983; Farias, 1990; Ribeiro et al., 1990a; Martinez-Catalán et al., 1999). The lowermost unit is autochthonous and consists of Upper Proterozoic sedimentary rocks uncomformably overlain by
Paleozoic strata that were deposited along the Gondwana shelf (Gutiérrez Marco et al., 1990; Pereira and Ribeiro, 1992; Sequeira, 1993).

The studied area is located in the Variscan kilometre-scale Viana do Castelo-Caminha antiform (Fig. 2), which is developed in the lower Paleozoic rocks located within the autochthonous unit in the most internal zone of the Variscan Belt, in the Central Iberian Zone (CIZ) (Fig. 1), which is characterized by the abundant Variscan granitoids and the widespread ductile deformation of the same age (Diez Balda et al., 1990; Dias, 1994). The main geological features of the study area, as described by Pereira et al. (1989), Cathileneau et al. (1993), Toyos (1995, 2003) and Pamplona (2001), are shown in a synthetic cross-section of the Viana do CasteloCaminha antiform (Fig. 3) and will be described in detail.

The rocks that crop out in the study area are mainly Variscan syn-orogenic granitoids (Fig. 2A) that intrude Upper Proterozoic shales and a sequence of Lower Paleozoic rocks (see synoptic lithostratigraphic column in Fig. 2B) composed of sandstones and conglomerates of the Cambrian Desejosa Formation, which is uncomformably overlain by the Arenigian Armorican Quartzite (Santa Justa Fm.) and shales of LanvirnLlandeilian age (Valongo Fm.). All host rocks have undergone LP-HT contact metamorphism related to the intrusion of the Variscan granitoids and have developed a paragenesis of garnet, andalusite (chiastolite up to $7 \mathrm{~cm}$ long), cordierite and scarce sillimanite. This LP-HT metamorphism (Hébert, 1997) masks most of the features of a previous Barrovian episode (Martinez et al., 1990; Ribeiro, 1992; Pamplona, 2001).

The structural evolution of the CIZ has been classically described to be comprised of three major deformation phases that occurred following each other along the Variscan Belt evolution (Dallmeyer et al., 1997 and references therein). According to some authors, the first deformation phase $\left(D_{1}\right)$ and the $D_{1}$ pervasive axial plane cleavage is related to either vertical or east-verging large scale folds developed in the earliest collisional stages (Diez Balda et al., 1990). Other authors, however, attribute the $\mathrm{D}_{1}$ cleavage to motion along left 


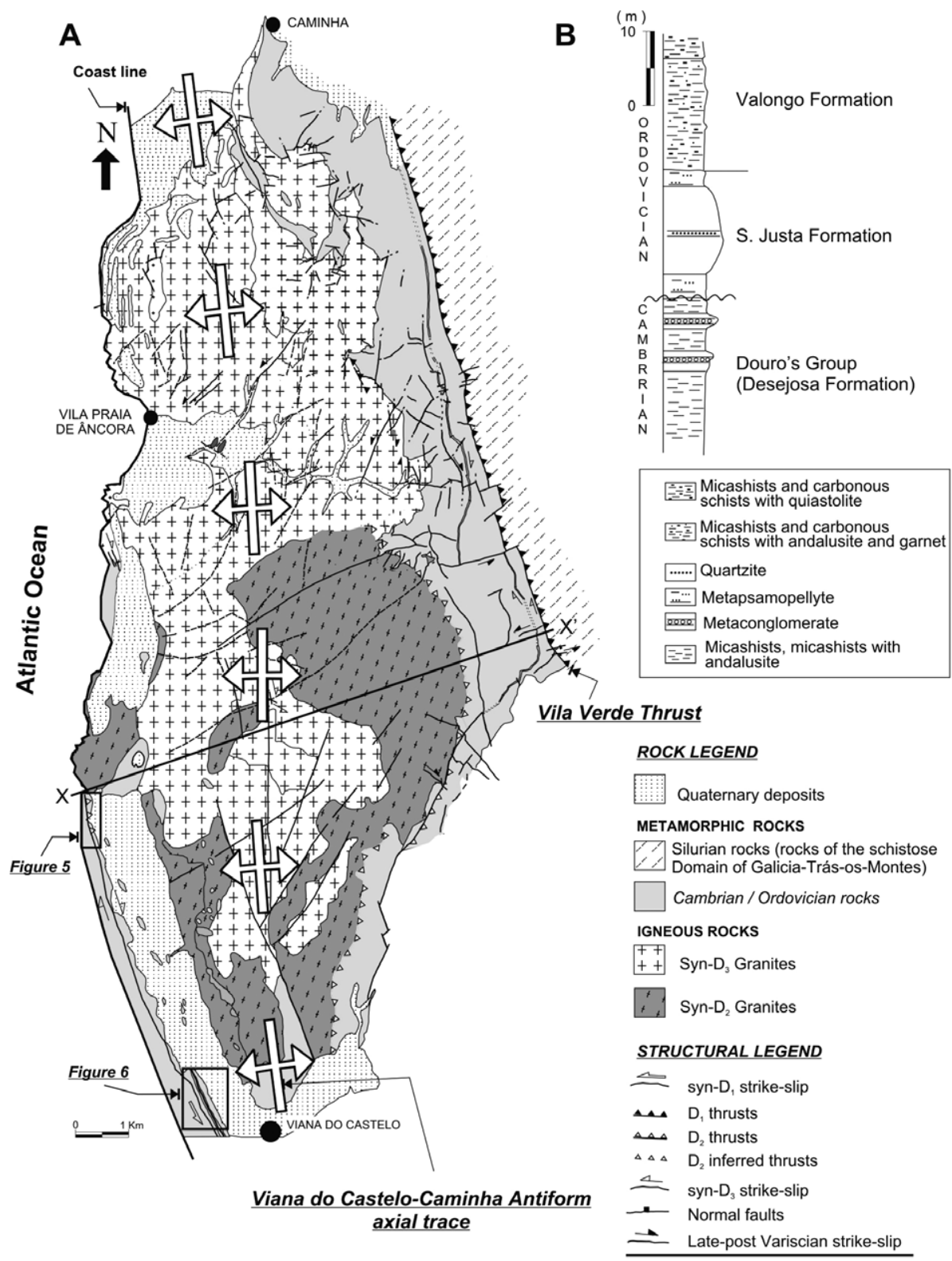

Fig. 2. (A) Geological map of the Viana do Castelo-Caminha antiform showing the axial trace of the studied antiform. (B) Synthetic lithostratigraphic column. X$\mathrm{X}^{\prime}$-cross-section in Fig. 3.

lateral shear zones that reflect a reactivation of a postulated Precambrian suture (Ribeiro et al., 1990a,b; Dias and Ribeiro, 1994). $D_{2}$ is characterized by the generation of top-to-the-east reverse shear zones related to the emplacement of the periGondwanan allochthonous units (Martinez-Catalán et al., 1999; Gómez Barreiro et al., 2006 and references therein). These shear zones are usually several kilometres thick and occur adjacent to the base of major thrusts that are responsible for the main shortening during the Variscan collision in NW Iberia. $\mathrm{D}_{3}$ results in the formation of late $\mathrm{N}-\mathrm{S}$-trending antiforms and synforms with vertical or east-dipping axial planes. Subsequently, $\mathrm{D}_{4}$ sub-vertical strike-slip faults and accompanying local shear zones are developed (Dias and Ribeiro, 1994, 1995; Llana-Fúnez and Marcos, 2001), although they are not generally considered to be part of a major widespread deformation event. These deformational events overlap in time, at least locally, and are clearly diachronous when considered at an orogenic scale (Dallmeyer et al., 1997).

The synthetic cross-section depicted in Fig. 3 depicts a large $\mathrm{D}_{3}$ antiform with a half wavelength of approximately $10 \mathrm{~km}$, which is characterized by many second order and minor folds with east-dipping steep axial planes (Fig. 4D) that commonly show axial plane crenulation cleavage. The minor fold axes predominantly plunge moderately to the south (Fig. 4D). At the western limit of the antiform, a semi-continuous outcrop of metasedimentary rocks is strongly deformed by a NNW-SSEtrending sub-vertical $\mathrm{D}_{3}$ dextral shear zone and is overprinted by late left-lateral local shear zones with the same orientation. Within this shear zone there are several large elongated, phacoid-shaped volumes of rock that preserve the most 


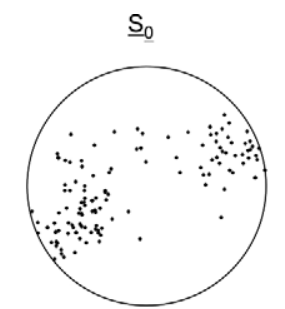

$\mathrm{N}=139$ Average value $347 / 42 E$
$\underline{\mathrm{S}}_{1}$

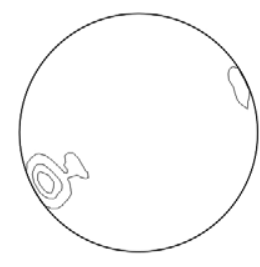

$10 \% ; 15 \% ; 30 \%$ $\mathrm{N}=127$ Average value
$335 / 78 \mathrm{E}$
$\underline{\mathrm{S}}_{2}$ - western flanc of antiform

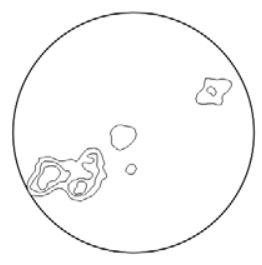

$10 \% ; 20 \% ; 30 \%$ $\mathrm{N}=152$ Average value

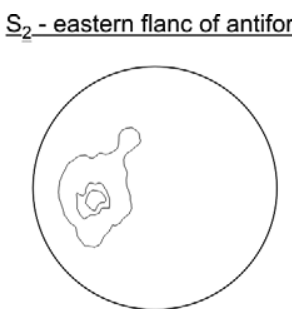

$5 \% ; 15 \% ; 20 \%$ $\mathrm{N}=173$ Average value

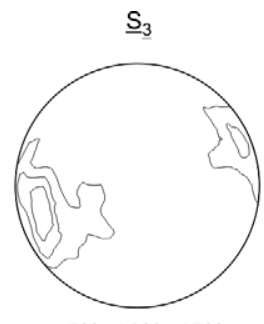

$5 \% ; 10 \% ; 15 \%$ $\mathrm{N}=183$ Average value

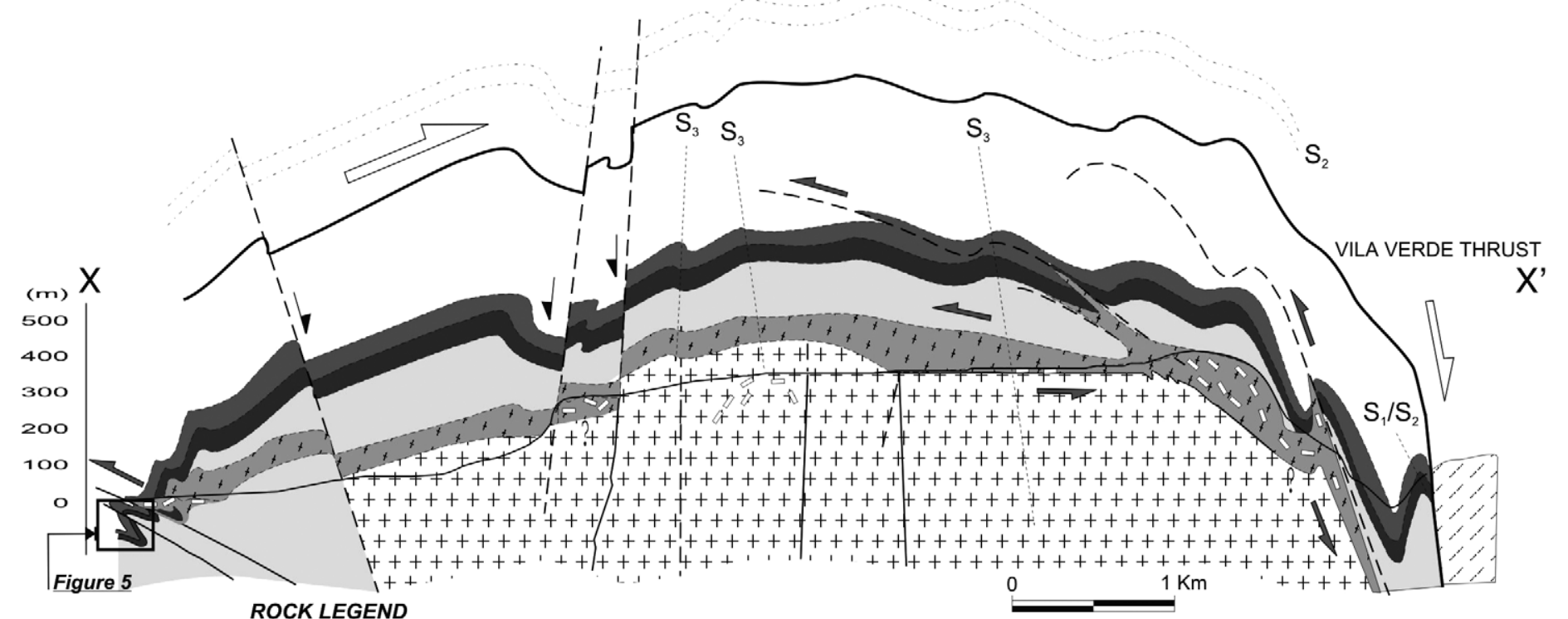

ROCK LEGEND

$\square$ Allochthonous $\square$ Lanvirnian-Landeilian $\square$ Arenigian-Tremadocian $\square$ Cambrian

+ Syn- $D_{3}$ Granite $t$ Syn- $D_{2}$ Granite

STRUCTURAL LEGEND

$\Longrightarrow$ Vila Verde Thrust

$\perp D_{2}$ shear sense

1 Post-Variscan faults

$\mathrm{D}_{2}$ shear sense _. _- Probable faults

\section{$\checkmark$ K-feldspar megacrystals}

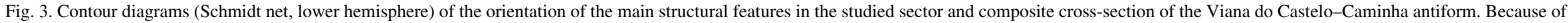
the general plunge of the structures to the North, most of the structures can be projected above the topographic surface. Location of the cross-section trace is in Fig. 2. Note the vertical exaggeration. 
A

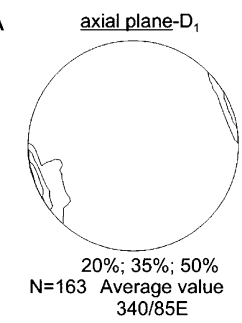

axial plane (sheath folds-Carreço)

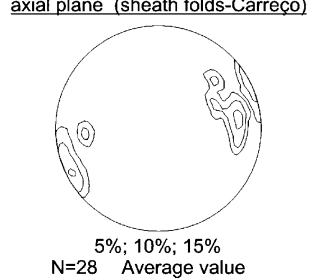

$\mathrm{B}$

stretching lineation - Praia Norte

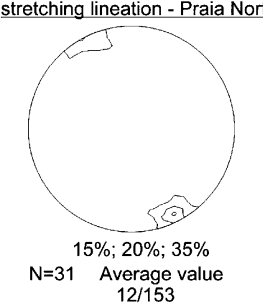

C

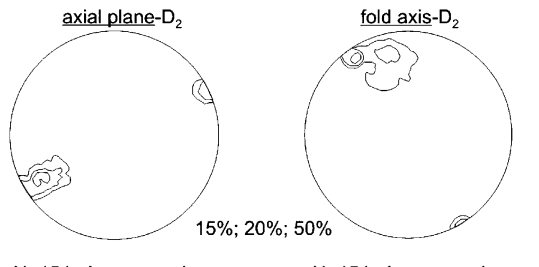

D
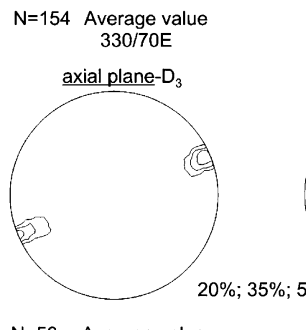

$\mathrm{N}=58 \quad$ Average value 346/84E

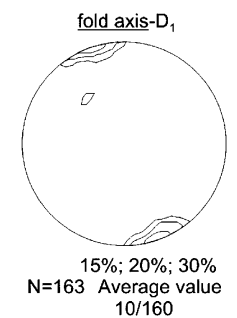

fold axis (sheath folds-Carreço)

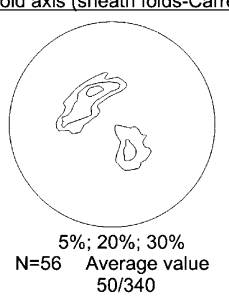

stretching lineation - CarreÁo

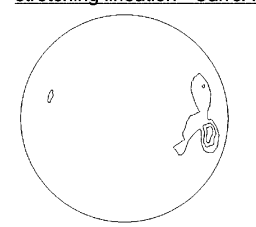

$10 \% ; 20 \% ; 40 \%$ $\mathrm{N}=25$ Average value $\mathrm{N}=154$ Average value $10 / 330$

fold axis- $\mathrm{D}_{3}$
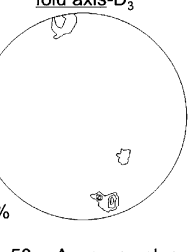
$14 / 166$
$\mathrm{N}=58 \quad$ Average value

Fig. 4. Contour diagrams (Schmidt net, lower hemisphere) of the main structural elements of the metasedimentary rocks present in the area. (A) Axial plane and fold axis of $D_{1}$. (B) Stretching lineation of $D_{1}$ in Praia Norte and Carreço. (C) Axial plane and fold axis of $\mathrm{D}_{2}$. (D) Axial plane and fold axis of $\mathrm{D}_{3}$. Explanation in the text.

competent quartzites much less deformed than the surrounding, strongly foliated, less competent slates and sandstones. Some of these phacoid-shaped rock bodies in Praia Norte (Fig. 2) show stratigraphic features of the Armorican quartzite, including trace fossils identified as bilobites, cross bedding and ripple marks. These phacoids also preserve primary tectonic structures such as the $S_{1}$ foliation, which is oblique to bedding and that has been interpreted to correspond to the $\mathrm{D}_{1}$ (Pamplona, 2001).

Above the Lower Paleozoic sequence, a large thrust, the Vila Verde Thrust (continued to the north as the Valdemiñotos Fault, Toyos, 2003), carried the parautochthonous units above

the Ordovician sediments towards the east (present-day coordinates). A $\mathrm{D}_{2}$ shear zone several kilometres thick accompanies this east moving thrust. This shear zone progressed into the autochthonous units and imparted a highly penetrative cleavage that is generally parallel to the thrust plane and to bedding obliterating $S_{1}$ in most cases. The $S_{2}$ cleavage was folded by the $D_{3}$ event and thus folded the $D_{2}$ thrust plane (Fig. 3).

The widespread granitoid rocks of this area are peraluminous granitoids intruded syn-kinematically with respect to $D_{2}$ and $\mathrm{D}_{3}$ deformation events (ca. 330-300 Ma) and are very abundant in NW Iberia. Some of the granitoid bodies of the studied region are interpreted to be intruded at the end of the $D_{2}$ event, but most of them are thought to be related to the $D_{3}$ event and some of them even later (Pamplona, 2001). These intrusions are responsible for the several generations of andalusite porphyroblast growth in the intruded sedimentary rocks.

\section{Structural features}

In order to understand the structural evolution of the studied region, two detail maps were completed in the areas where high quality coastal exposures allowed the structural relationships between the different shear zones to be clearly observed and understood. The two areas studied in detail are Carreço beach (Fig. 5) and Praia Norte beach (Fig. 6). The most prominent structures found in the aforementioned studied areas are folds and several sets of cleavage, which show different characteristics depending on which of the three main Variscan deformation phases they are related to.

\subsection{First Variscan deformation phase $\left(D_{1}\right)$}

\subsubsection{Structures: folds, cleavage and stretching lineation}

The only $\mathrm{D}_{1}$ folds recognized are isoclinal and are preserved only in the less deformed, lens shaped, quartzite bodies of the Santa Justa Formation. These folds (Fig. 7A) have sub-vertical axial planes $\left(340^{\circ} / 85^{\circ} \mathrm{E}\right)$ and sub-horizontal fold axis (Fig. 4A). In addition, there are some small scale sheath folds developed in the Santa Justa Fm. quartzites that are also assigned to $D_{1}$. The axial planes of these sheath folds are sub-vertical and subparallel to the $\mathrm{D}_{1}$ isoclinal folds (mean orientation: $344^{\circ} / 80^{\circ} \mathrm{W}$ ) and the fold axis defines a sheath-like girdle along this mean orientation (Fig. 4A).

$D_{1}$ folds are characterized by a sub-vertical cleavage $\left(S_{1}\right)$, parallel (or almost parallel) to their axial plane (mean orientation of $335^{\circ} / 78^{\circ} \mathrm{E}$; Fig. 3). This cleavage is well developed in the Santa Justa quartzites, but has been obliterated in the less competent lithologies. Locally, however, this cleavage has transecting relationships with respect to $D_{1}$ axial planes, especially in the Praia do Norte outcrop where the axial planes of folds $\left(335^{\circ} / 90^{\circ}\right)$ are transected more than $10^{\circ}$ by the $\mathrm{S}_{1}$ cleavage $\left(345^{\circ} / 80^{\circ} \mathrm{NE}\right)$.

A pervasive stretching lineation, attributed to $D_{1}$ shows two different orientations (Fig. 4B): in the Praia do Norte sector the 


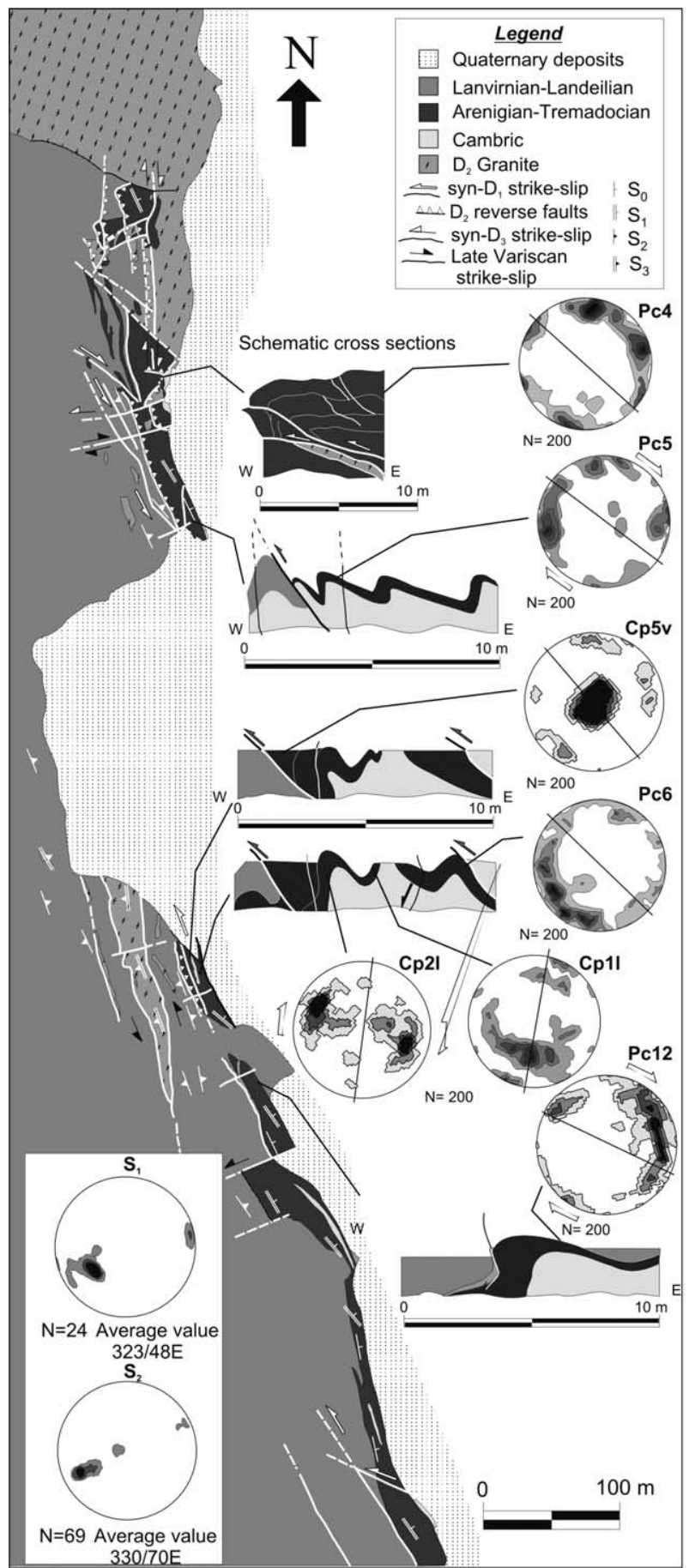

Fig. 5. Detailed geologic map of Carreço area with CPOs (density intervals $1 \%)$, schematic cross-sections and stereographic projections, Schmidt net, lower hemisphere. Location in Fig. 2.

mean orientation is $12^{\circ} / 153^{\circ}$ and in the Carreço sector is $18^{\circ} \%$ $100^{\circ}$.

\subsubsection{Interpretation of $D_{1}$ in the studied sector}

$\mathrm{D}_{1}$ isoclinal and sheath folds, and the others preserved in the quartzite phacoids, are interpreted to be related mainly to shear zone development during the emplacement of the allochthonous units to the east above the Vila Verde thrust (Ribeiro et al., 1990a). Unfortunately, the sheath folds do not show a marked asymmetry and do not indicate clearly the topto-the-east sense of movement of the Vila Verde thrust, presumably due to the subsequent deformation, mostly the steepening of the $\mathrm{D}_{1}$ folds during the $\mathrm{D}_{2}$ and $\mathrm{D}_{3}$ deformations (see below). Transection of some of the $\mathrm{D}_{1}$ folds can be explained by the dextral transpressive nature of the $D_{1}$ deformation in this sector of the Variscan Belt of NW Iberia (Ribeiro et al., 1990a).

Following the same reasoning, both orientations of the stretching lineation are interpreted to reflect the dextral transpressive and progressive nature of the $\mathrm{D}_{1}$ deformation. The E-W-trending lineation can be explained in relation to the early stages of the Vila Verde thrust emplacement, while the $\mathrm{N}-\mathrm{S}$ one is related to the left lateral strike-slip component (Ribeiro et al., 1990a).

\subsection{Second Variscan deformation phase $\left(D_{2}\right)$}

\subsubsection{Structures: folds and cleavage}

$\mathrm{D}_{2}$ is characterized by the presence of abundant folds that are tight to isoclinal that can be recognized only in the Carreço sector affecting the previous $S_{1}$. The density contour diagrams of the $\mathrm{D}_{2}$ axial planes and fold axis (Fig. 4C) show mean values of $330^{\circ} / 70^{\circ} \mathrm{E}$ and $10^{\circ} / 330^{\circ}$, respectively, but some folds have more shallowly dipping $\left(<30^{\circ}\right)$ axial planes.

The $\mathrm{D}_{2}$ shear cleavage (Fig. 7D and E) dips mostly to the NE showing a different attitude (dip values) in both flanks of the Viana do Castelo-Caminha antiform (Fig. 3). The $\mathrm{D}_{2}$ cleavage appears concentrated within bands parallel to the $\mathrm{D}_{2}$ thrusts, crenulates the previous $S_{1}$ and shows kinematic criteria, both indicating top-to-the-west and top-to-the-east movements.

\subsubsection{Interpretation of $D_{2}$ in the studied sector}

The origin of the $\mathrm{D}_{2}$ structures is interpreted to be related to the emplacement of the Vila Verde thrust. Conjugate, top-tothe-west, minor thrusts developed in the footwall of the main thrust, as can be seen in Fig. 3. Several laminar granitoid bodies were emplaced in orientations that are parallel with $D_{2}$ thrusts and are thought to be early syn- $\mathrm{D}_{2}$, having been rotated to their present attitude by the progressive $\mathrm{D}_{2}$ shear zones.

In addition, the studied sector is the only domain of the West Iberian Variscan Belt described so far where it is possible to document the rapid passage of the $\mathrm{D}_{1}$ strike-slip structures to late $D_{1}$ or early $D_{2}$ east vergent flat-lying structures.

\subsection{Third Variscan deformation phase $\left(D_{3}\right)$}

\subsubsection{Structures: folds and cleavage}

Ubiquitous $\mathrm{D}_{3}$ structures were formed during the last main Variscan deformational event. $\mathrm{D}_{3}$ cylindrical folds are predominantly steep, shallowly plunging, open structures with mean axial plane and fold axis orientations of $346^{\circ} / 84^{\circ} \mathrm{E}$ and $14^{\circ} / 166^{\circ}$, respectively (Fig. 4D), and produce type 3 interference patterns (Fig. 7C) with both $\mathrm{D}_{1}$ and $\mathrm{D}_{2}$ isoclinal folds. In the region between Carreço and Praia Norte, the $\mathrm{D}_{3}$ have interlimb angles of about $135^{\circ}$. 


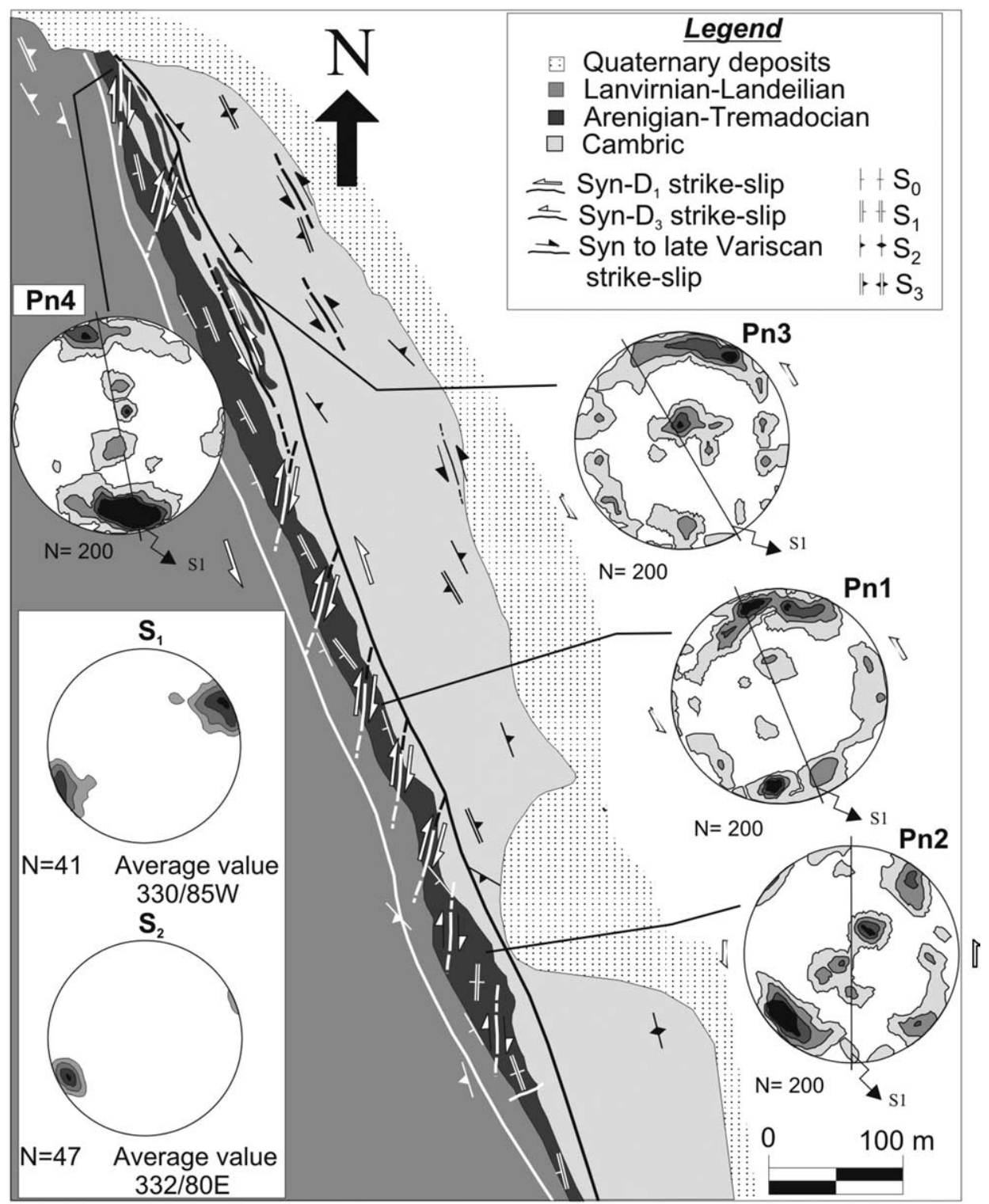

Fig. 6. Detailed geologic map of Praia Norte area with CPOs (density intervals 1\%) stereographic projections, Schmidt net, low hemisphere. Location in Fig. 2.

$D_{3}$ folds deform pre-existing $\left(D_{1}\right.$ and $\left.D_{2}\right)$ cleavages. $S_{3}$ has a mean orientation oriented $345^{\circ} / 72^{\circ} \mathrm{E}$ (Fig. 3), parallel to the axial planes of the $\mathrm{D}_{3}$ folds. This cleavage is not prevalent across the whole region and is most commonly observed in the fine grained metasediments. According to the field data, $S_{3}$ surfaces contain local sub-horizontal stretching lineation parallel to the fold axis. Parallel to the stretching lineation there is microscopic evidence of dextral kinematic criteria (Fig. 7F). Pre- or syn- $\mathrm{D}_{3}$ granitoid bodies are also affected by this deformation, developing $\mathrm{S}-\mathrm{C}$ fabrics with mostly dextral asymmetry.

Rare late $\mathrm{D}_{3}$ structures have been recognized in the study area: NE-SW open folds that produce type 1 interference patterns with previous folds and also non-pervasive, little penetrative cleavage, kink bands and $\mathrm{N} 10^{\circ} \mathrm{E}-\mathrm{N} 40^{\circ} \mathrm{W}$ leftlateral deformational corridors affecting the latest aplitic and pegmatitic dykes not deformed by the $\mathrm{D}_{3}$ in the region.

\subsubsection{Interpretation of $D_{3}$ in the studied sector}

We can interpret $\mathrm{D}_{3}$ to reflect either a switch from dextral to a left lateral transpressive regime or to the presence of a conjugate set of transcurrent shear zones coeval with the E-W shortening that gave rise to the open folds. This event took place under ductile to brittle conditions producing abundant en échelon vein arrays. It is probable also that the abundance of previous already cooled granitoid bodies surrounding the studied region caused a deformation shadow in this area during the $\mathrm{D}_{3}$ event, which may explain its low intensity compared with the same event in surrounding areas.

\section{Quartz CPOs}

Quartz crystallographic preferred orientation (CPO) studies (Wenk and Christie, 1991) of deformed polycrystalline aggregates can provide constraints on the kinematics and 


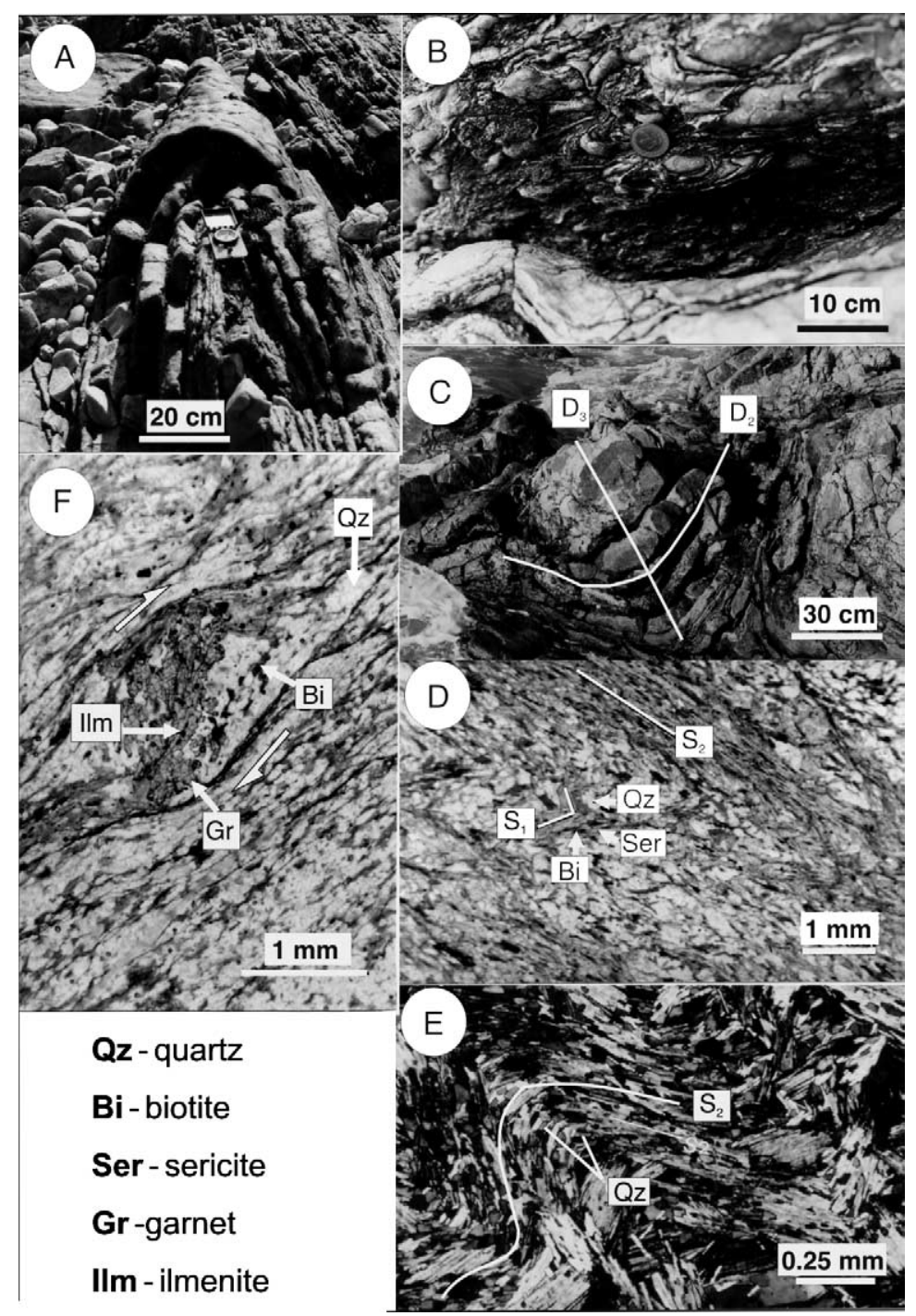

Fig. 7. Field ((A)-(C)) and microscope photos ((D)-(F)). (A) $D_{1}$ fold in the Armorican Quartzite; (B) $D_{1}$ sheath folds in the Armorican Quartzite; (C) $D_{3}$ fold folding a $\mathrm{D}_{2}$ fold in the Armorican Quartzite; (D) crenulated $\mathrm{S}_{1}$ and $\mathrm{S}_{2}$ in the Cambrian micashists; (E) $\mathrm{D}_{3}$ crenulation in the Cambrian micashists; (F) $\mathrm{D}_{3}$ dextral cinematic criteria in the Cambrian garnet bearing micashists.

deformation conditions in rocks deformed under ductile conditions and the relationship between simple shear and the interference of flow geometries (Llana-Fúnez, 2002). However, in many cases, an important component of pure shear and coaxial overprints is needed to unambiguously interpret some texture elements (Lister and Dornsiepen, 1982; Hobbs, 1985). Because of the complex structure and strain superposition within the studied region, CPO studies can provide useful constraints on the nature of the different deformation phases (especially the earlier phases where they are not modified subsequently), the conditions in which they developed and the deformation mechanisms involved in the generation of the ductile shear zones.

\subsection{Objective and sampling strategy}

We used the quartz CPOs in order to try to deduce the structural relationships and kinematics of the $\mathrm{D}_{1}$ structures developed in the shear zones and the relationships among them.
Oriented samples from the Santa Justa Fm. (the Armorican Quartzite) in the two areas studied in detail were collected in order to compare and understand the two different deformation patterns observed in them. These areas have different orientation to the $\mathrm{D}_{1}$ structures and show different recrystallization histories. Samples were collected along both limbs of the post- $\mathrm{D}_{1}$ folds in order to explore the effect of re-folding and to understand the kinematics of the $\mathrm{D}_{1}$ deformation.

All oriented samples were studied in thin sections cut on the $\mathrm{XZ}$ plane, in sections normal to the $\mathrm{D}_{1}$ cleavage $\left(\mathrm{S}_{1}\right)$ and parallel to the observed $\mathrm{L}_{1}$ stretching lineation. Because of its complex deformation and metamorphic history, samples with evidence of intense late-Variscan static recrystallization or with strong crenulations affecting the $S_{1}$ were rejected.

\subsection{Description of the CPOs}

The Santa Justa quartzite studied samples are composed originally of $99 \%$ quartz xenomorphic grains that, when 
deformed, range from slightly elongated to irregular. The grain boundaries are commonly sutured although rare rectilinear contacts are also observed.

CPOs analyses were performed using a manually operated U-Stage and the orientation of quartz c-axes are plotted on stereonets (Fig. 5: Carreço outcrop; Fig. 6: Praia Norte). The kinematic vectors are oriented in relation to the orientation of the structures (cleavage and lineation) present in the studied sections.

In the Carreço and Praia Norte outcrops, the quartz c-axis distribution patterns are different in all studied samples. For example, the patterns of samples Pc4 and Pc6 (Fig. 5) are highly symmetric and indicate predominantly coaxial deformation. Cp11 (Fig. 5) and Pn4 (Fig. 6) depict an orthorhombic pattern that may reflect symmetric coaxial extension (Twiss and Moores, 1992). Sample Cp5v also depicts a CPO coaxial deformation type, although its high temperature nature precludes a thorough kinematic interpretation.

$\mathrm{CPO}$ patterns in the more deformed samples are asymmetric (type II crossed girdle pattern; Twiss and Moores, 1992) with respect to both the foliation plane and the stretching lineation, features that are interpreted to provide shear sense indicators in non-coaxial deformation (Lister and Williams, 1979). Samples Pc5, Cp21 and Pc12 from the Carreço outcrop (Fig. 5) and samples Pn1, Pn2 and Pn3 from Praia Norte (Fig. 6) all show a low temperature non-coaxial deformation pattern with asymmetrical type II girdles. The Carreço samples indicate a top-tothe-east thrust component, whereas the Praia Norte samples imply left-lateral movements.

\subsection{Interpretation of the CPOs}

The appearance of different morphologies of quartz CPOs and quartz grains is attributed to the sequential and progressive deformation from ribbon to irregular to polygonal grains (Llana-Fúnez, 2002) and to an increasing role of grain boundary migration as the recrystallization mechanism during regional deformation. The studied samples can be interpreted in the light of an overall noncoaxial deformation that produced a concentration of the quartz c-axis orientations by the slip of the [a] basal planes. The type II maxima present in the girdles are related to the slip in the rhombohedrical planes (r)[a] and (z)[a] as illustrated in the sample $\mathrm{Cp} 21$ as well as the type III maxima present in samples Pc5, Pc12, Pn1, Pn2 and Pn3, all of them related to the (0001)[a] slip system.

The presence of coaxial quartz c-axis patterns may reflect strain partitioning within narrow (decametric to kilometric) shear corridors according to the 2D and 3D finite strain patterns obtained in the Viana do Castelo-Caminha antiform (Pamplona et al., 1997; Pamplona, 2001) and adjacent areas (Coke et al., 2003) where the bedding surfaces acted as the main anisotropy controlling the style of deformation.

The fabric in the sample depicting a high temperature deformation (Cp5v; Fig. 5) is interpreted to be synchronous with respect to the $\mathrm{D}_{1}$ deformation (at least the late stages) and with early $\mathrm{D}_{2}$ magmatism.
Furthermore, the shear senses obtained in the CPOs are congruent with the regional and field evidence and support the different style of $\mathrm{D}_{1}$ deformation in the Carreço and Praia Norte outcrops. The results obtained in Carreço are in general agreement with the overall interpretation of the late $\mathrm{D}_{1}$ or early $\mathrm{D}_{2}$ deformation in this sector of the Variscan Iberian belt, which includes the earlier stages of the east-directed thrusting of the allochthonous units above the autochthonous ones (Fig. 8A).

The kinematic results obtained from the CPOs in Praia Norte are attributed to left lateral transpression that is widely recognized in the autochthonous units of CIZ and Galicia-Trasos-Montes (Fig. 8B).

\section{Kinematic history of the Viana do Castelo antiform}

Fig. 8 illustrates and summarizes the Variscan deformational history of the studied region and adjacent areas. It starts with the $\mathrm{D}_{1}$ deformation event, which is responsible for the corval left lateral transpression and the early thrust emplacement of the allochthonous terranes (Fig. 8A and B).
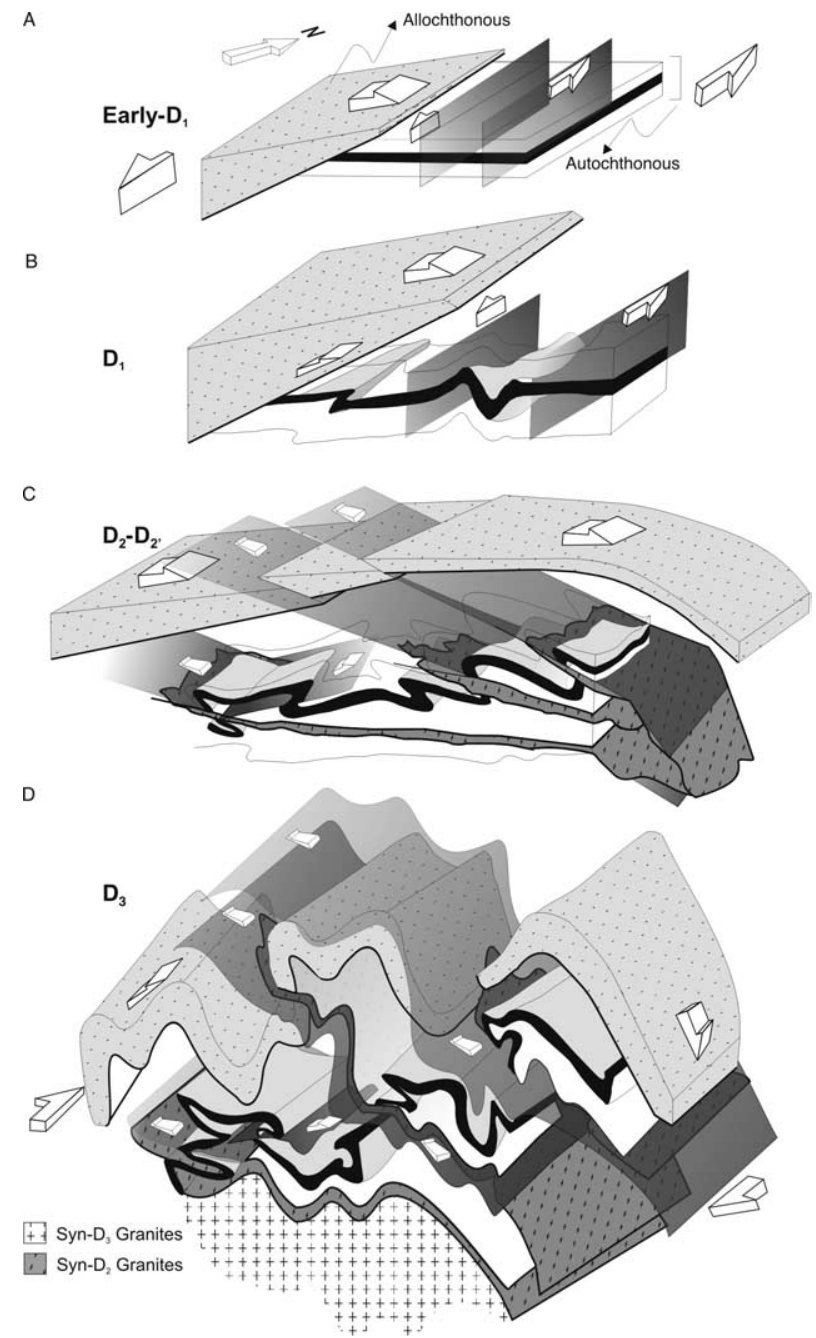

Fig. 8. Sequential diagrams ((A)-(D)) summarizing and depicting the evolution of the different Variscan deformation phases as recognized in the studied area (antiform of Viana do Castelo-Caminha). 
Further deformation events did not affect the $\mathrm{D}_{1} \mathrm{CPO}$ of the studied samples and the succession of events can be reconstructed from the analysis of the meso- and microstructures already mentioned. From this point of view the structural history, after the $\mathrm{D}_{1}$ event, of the studied region can be summarized as follows:

1. The continental collision during the $\mathrm{D}_{2}$ event was responsible for the development of $\mathrm{E}$ and $\mathrm{W}$ dipping reverse shear zones. The intrusion of syn-kinematic laminar granitoid bodies along the shear zones is the dominant $\mathrm{D}_{2}$ feature in this area (Fig. 8C).

2. $\mathrm{D}_{3}$ is characterized by shear corridors, $0.5 \mathrm{~km}$ wide, related to dextral transpression that resulted in open folds, conjugate shears and refolding the previous folds, cleavages, thrusts, shear zones $\left(D_{1}\right.$ and $\left.D_{2}\right)$ and the early granites sheets. In addition, the voluminous late-Variscan syn- $\mathrm{D}_{3}$ granitoids were emplaced in the core of the $\mathrm{D}_{3}$ Viana do Castelo-Caminha antiform (Fig. 8D).

3. Late $\mathrm{D}_{3}$ left-lateral transpressive deformation is characterized by the reactivation of earlier shear zone corridors and the development of a weak folding and cleavage.

\section{Conclusions}

The Viana do Castelo-Caminha antiform is a region where the main deformation events in the autochthonous units of the Variscan Iberian Belt are well represented and its relations can be well understood. Field data and CPO studies in quartzitic rocks of the Santa Justa Fm. allow the reconstruction of the earlier episodes of the Variscan deformation despite the complex evolution and the strong thermal imprint along the subsequent Variscan deformation and magmatic events.

The two areas studied in detail provide evidence for the different components of $\mathrm{D}_{1}$ deformation, pure shear and transpression that occurred in the autochthonous units below the Vila Verde thrust.

A complete geological history of the studied region, regarding the Variscan deformation, can be reconstructed, showing the complex evolution along the main tectonic events (Fig. 8). The colliding process between Laurentia and Gondwana in the studied sector involved large scale strain partition in time and space between transpressional and orogenic-normal deformations in the most internal parts of the Variscan Belt.

This study proves the need to produce alternative, noncylindrical, deformation models to develop new ideas in the Variscan orogen in order to fully understand the evolution of its complex kinematic history, especially the transpressional events that are often overlooked and understated.

\section{Acknowledgements}

Partial funding to GGA was provided by project BTE200305128 from the Spanish "Ministerio de Ciencia y Tecnología". Partial funding to JP was provided by the Fundação para a
Ciência e Tecnologia. Very insightful and helpful reviews were done by J.B. Murphy, J. Weber and an anonymous reviewer, which are greatly acknowledged.

\section{References}

Aranguren, A., Tubía, J.M., 1994. Características estructurales y modelo de emplazamiento del Plutón de Guitiriz (Galicia). Revista de la Sociedad Geológica de España 7, 63-73.

Arenas, R., Gil Ibarguchi, J.I., González Lodeiro, F., Klein, E., Martínez Catalán, J.R., Ortega Gironés, E., de Pablo Maciá, J.G., Peinado, M., 1986. Tectonostratigraphic units in the complexes with mafic and related rocks, NW of the Iberian Massif. Hercynica II, 87-110.

Arenas, R., Rubio Pascual, F.J., Díaz García, F., Martínez Catalán, J.R., 1995. High pressure micro inclusions and development of an inverted metamorphic gradient in the Santiago schists (Ordenes Complex, NW Iberian Massif, Spain): evidence of subduction and syn-collisional decompression. Journal of Metamorphic Geology 13, 141-164.

Cathileneau, M., Boirón, M.C., Essarraj, S., 1993. Major structural factors of Au concentrations in the northwestern Iberian Massif (Spain-Portugal): a multidisciplinary and multiscale study. Proceedings of the Second Biennial SGA Meeting "Current research in geology applied to ore deposits", Granada, pp. 613-616.

Coke, C., Dias, R., Ribeiro, A., 2003. Rheologically induced structural anomalies in transpressive regimes. Journal of Structural Geology 25, 409420.

Dallmeyer, R.D., Martínez Catalán, J.R., Arenas, R., Gil Ibarguchi, J.I., Gutiérrez-Alonso, G., Farias, P., Bastida, F., Aller, J., 1997. Diachronous variscan tectonothermal activity in the NW Iberian Massif: evidence from ${ }^{40} \mathrm{Ar} /{ }^{39} \mathrm{Ar}$ dating of regional fabrics. Tectonophysics $277,307-337$.

Dias, R., 1994. Regimes de deformação no autóctone da Zona Centro-Ibérica: importância para a compreensão da génese do Arco Ibero-Armoricano. Ph.D. thesis, Universidade de Lisboa.

Dias, R., Ribeiro, A., 1994. Constriction in a transpressive regime: an example in the Iberian branch of the Ibero-Armorican Arc. Journal of Structural Geology 16 (11), 1543-1544.

Dias, R., Ribeiro, A., 1995. The Ibero-Armorican Arc: a collision effect against an irregular continent? Tectonophysics 246, 113-128.

Diez Balda, M., Vegas, R., Gonzalez Lodeiro, F., 1990. Structure. In: Dallmeyer, R.D., Martinez Garcia, E. (Eds.), Pre-Mesozoic Geology of Iberia. Springer-Verlag, Berlin, pp. 172-188.

Farias, P., 1990. La geología de la Región del Sinforme de Verín (Cordillera Herciniana, NW de España). Laboratorio Xeolóxico de Laxe, Serie Nova Terra 2.

Fernández-Suárez, J., Díaz García, F., Jeffries, T.E., Arenas, R., Abati, J., 2003. Constraints on the provenance of the uppermost allochthonous terrane of the NW Iberian Massif: inferences from detrital zircon U-Pb ages. Terra Nova 15, 138-144.

Ferreira, N., Iglesias, M., Noronha, F., Pereira, E., Ribeiro, A., Ribeiro, M.L., 1987. Granitóides da zona Centro-Ibérica e seu enquadramento geodinâmico. In: Bea, F., Carnicero, A., Gonzalo, J.C., Lópes Plaza, M., Rodriguez Alonso, M.D. (Eds.), Geologia de los granitoides y rocas asociadas del Macizo Hespérico (Libro de homenage a Garcia Figuerola). Editorial Rueda, Madrid, pp. 37-51.

Gómez Barreiro, J., Wijbans, J.R., Castiñeiras, P., Martinez Catalan, J.R., Arenas, R., Diaz García, F., Abati, J., 2006. ${ }^{40} \mathrm{Ar} /{ }^{39} \mathrm{Ar}$ laserprobe dating of mylonitic fabrics in a poliorogenic terrane of NW Iberia. Journal of the Geological Society, London 163, 61-73.

Gutiérrez-Alonso, G., Fernández-Suárez, J., Weil, A.B., 2004. Orocline triggered lithospheric delamination. In: Sussman, A., Weil, A.B. (Eds.), Paleomagnetic and Structural Analysis of Orogenic Curvature. Geologic Society of America Special Paper 383, pp. 121-131.

Gutiérrez Marco, J., San José, M., Pieren, A., 1990. Post-Cambrian Paleozoic stratigraphy. In: Dallmeyer, R.D., Martinez Garcia, E. (Eds.), Pre-Mesozoic Geology of Iberia. Springer-Verlag, Berlin, pp. 160-171. 
Hébert, R., 1997. Mineral and fluid thermobarometry within the Variscan shear zone of Monteferro-El Rosal (NW Galicia, Spain): a preliminary investigation. Terra Nova 9, 24-27.

Hobbs, B.E., 1985. The geological significance of microfabric analysis. In: Wenk, H.R. (Ed.), Preferred Orientation in Deformed Metals and Rocks: An Introduction to Modern Texture Analysis. Academic Press, New York, pp. 463-484.

Iglesias, M., Choukroune, P., 1980. Shear zones in the Iberian Arc. Journal of Structural Geology 2, 63-68.

Iglesias, M., Ribeiro, M.L., Ribeiro, A., 1983. La interpretación aloctonista de la estrutura del Noroeste Peninsular. In: Geologia de Espana, Libro Jubilar J.M. Rios, IGME, pp. 459-467.

Lister, G., Dornsiepen, U., 1982. Fabric transitions in the Saxony granulite terrain. Journal of Structural Geology 4, 81-92.

Lister, G., Williams, P., 1979. Fabric development in shear zones: theoretical controls and observed phenomena. Journal of Structural Geology 1 (4), 283-297.

Llana-Fúnez, S., 2002. Quartz c-axis texture mapping of a Variscan regional foliation (Malpica-Tui Unit, NW Spain). Journal of Structural Geology 24, 1299-1312.

Llana-Fúnez, S., Marcos, A., 2001. The Malpica-Lamego Line: a major crustalscale shear zone in the Variscan Belt of Iberia. Journal of Structural Geology 23, 1015-1030.

Marques, F., Ribeiro, A., Munhá, J., 1996. Geodynamic evolution of Continental Allochtonous Terrain (CAT) of the Bragança Nappe Complex, NE Portugal. Tectonics 15, 747-762.

Martinez, F., Corretge, L., Suarez, O., 1990. Distribution, characteristics and evolution of metamorphism. In: Dallmeyer, R.D., Martinez Garcia, E. (Eds.), Pre-Mesozoic Geology of Iberia. Springer-Verlag, Berlin, pp. 207-211.

Martinez-Catalán, J.R., Arenas, R., Díaz García, F., Pascual, F.J., Abati, J., Marquínez, J.L., 1996. Variscan exhumation of a subducted Paleozoic continental margin: the basal units of the Ordenes Complex, Galicia, NW Spain. Tectonics 15, 106-121.

Martinez-Catalán, J.R., Arenas, R., Díaz García, F., Abati, J., 1999. Allochthonous units in the Variscan Belt of NW Iberia. Terranes and accretionary history. In: Sinha, A.K. (Ed.), Basement Tectonics. Kluwer Academic Publishers, pp. 65-84.

Matte, Ph., Ribeiro, A., 1975. Forme et orientation de l'ellipsoïde de déformation dans la virgation hercyenne de Galice. Relations avec le plissement et hypothèses sur la genèse de l'árc ibéro-armoricain. Comptè Rendus de l'Académie des Sciences de la Terre Paris 280, 2825-2827.
Pamplona, J., 2001. Tectónica do Antiforma de Viana do Castelo-Caminha (ZCI). Regime de defromação e instalação de granitóides. Ph.D. thesis. Universidade do Minho, 191pp.

Pamplona, J., Dias, R., Ribeiro, A., 1997. Heterogeneidade da transpressão varisca no Autóctone da Zona Centro-Ibérica; evidências a partir da quantificação da deformação em Viana do Castelo (NW Portugal). Comunicações da XIV Reunião de Geologia do Oeste Peninsular, Vila Real, pp. 169-172.

Pereira, E., Ribeiro, A., 1992. Paleozóico: Estratigrafia. In: Notícia Explicativa da Folha 1 da Carta Geológica de Portugal à escala 1:200,000. E. Pereira (coord.), Serviços Geológicos de Portugal, pp. 9-22.

Pereira, E., Ribeiro, A., Carvalho, G., Noronha, F., Ferreira, N., Monteiro, J.H., 1989. Carta Geológica de Portugal à escala 1:200,000, folha 1, Serviços Geológicos de Portugal, Lisboa.

Ribeiro, M.L., 1992. Metamorfismo-observações gerais sobre o metamorfismo na Península Ibérica. In: Notícia explicativa da Folha 1 da Carta Geológica de Portugal à escala 1/200 000. E. Pereira (coord.), Serviços Geológicos de Portugal, pp. 22-27.

Ribeiro, A., Pereira, E., Dias, R., 1990a. Structure in the Northwest of Iberia Peninsula. In: Dallmeyer, R.D., Martinez Garcia, E. (Eds.), Pre-Mesozoic Geology of Iberia. Springer-Verlag, Berlin, pp. 220-236.

Ribeiro, A., Quesada, C., Dallmeyer, R.D., 1990b. Geodynamic evolution of the Iberian Massif. In: Dallmeyer, R.D., Martinez Garcia, E. (Eds.), PreMesozoic Geology of Iberia. Springer-Verlag, Berlin, pp. 399-409.

Sequeira, A., 1993. Provável discordância intra-Grupo das Beiras na região entre Monfortinho e Idanha-a-Nova. Comunicações da XII Reunião de Geologia do Oeste Peninsular, Évora 1, 41-52.

Toyos, J.M., 1995. Estructura y mineralizaciones auríferas del área de Tomiño (Pontevedra). Ph.D. thesis, Universidad de Oviedo, 212pp.

Toyos, J.M., 2003. Litoestratigrafía de la banda esquistosa de Monteferro-El Rosal (Macizo Ibérico, Provincia de Pontevedra). Revista de la Sociedad Geológica de España 16 (3-4), 213-226.

Twiss, R.J., Moores, E.M., 1992. Structural Geology. W.H. Freeman and Company, New York. 532pp.

Weil, A., Van der Voo, R., van der Pluijm, B.A., 2001. Oroclinal bending and evidence against the Pangea megashear: the Cantabria-Asturias arc (northern Spain). Geology 29, 991-994.

Wenk, H.-R., Christie, J.M., 1991. Comments on the interpretation of deformation textures in rocks. Journal of Structural Geology 13, 1091-1110. 